\title{
Title Acute efavirenz intoxication in a 16-year-old HIV negative girl: A case report and literature review
}

\author{
Minoo Moghimi ${ }^{1}$, Zahra Nekoukar ${ }^{2}$, and Navid Khosravi ${ }^{1}$ \\ ${ }^{1}$ Mazandaran University of Medical Sciences \\ ${ }^{2}$ Mazandaran University of Medical Sciences Faculty of Pharmacy
}

January 26,2022

\begin{abstract}
Abstract We present an acute intoxication with 12 grams of efavirenz (EFV) in a 16-year-old healthy girl whose main problem was neurotoxicity which is dose-dependent. No other serious EFV-related side effects were seen. Previous serious side effects of EFV were observed in HIV-infected patients who underwent long-term combination drug therapy.
\end{abstract}

\section{Hosted file}

Efavirenz Manuscript.docx available at https://authorea.com/users/457316/articles/554141title-acute-efavirenz-intoxication-in-a-16-year-old-hiv-negative-girl-a-case-reportand-literature-review 